\title{
Strategies of South African professional firms - an empirically grounded typology
}

\author{
Faith Botha* \& Mark Orkin \\ Faculty of Management, University of the Witwatersrand, 2 St David's Place, Parktown, Johannesburg 2193 \\ Republic of South Africa
}

Received February 1992, accepled June 1993

\begin{abstract}
Professional organizations are facing a number of environmental challenges in South Africa in the 1990. The options open to them in successfully positioning their organizations in the face of these challenges presented the research problem. Professional organizations were researched from the perspective of integrated achetypes of organizational form, strategy and the perceptions and values of the top management team. The research was conducted on 56 prominent professional organizations from six professions in South Africa, with an inductive research approach being laken. Theory indicated four possible options and three instruments were developed and tested to test the theory among the partners and stakeholders of the firms. Multivariate techniques of factor and cluster analysis were applied to the resulting data, and the findings indicated five broad configurations of adaptation, three of which concurred with the theory. the fourth which was positioned across the boundaries of two of the theoretical options, and the fifth which wa positioned along a third dimension to that suggested by the theory, namely, that of the collective values of the top management team. It appeared that a large number of professional organizations in South Africa still operate successfully from the basis of their professional reputation, but that equally, a number have also adopted more innovaive approaches.
\end{abstract}

Professionele organisasies in Suid-Afrika kom in die 1990's voor 'n hele pasr ongewingsuildagings le aran. Die moontlikhede om hulleself te midde van dié uitdagings suksesvol te posisioneer, is onbeperk en het die navorsingsprobleem opgelewer. Professionele organisasie is nagevors vanuit die perspektief van geïntegreerde agetipiese organisatoriese strukture, strategiee en die persepsies en waardes van die topbestuurspan. Die navorsing is gedoen op 56 prominente professionele organisasies in Suid-Afrika en 'n induktiewe benadering is ten opsigte van die navorsing gevolg. Die teorie het vier moontlike opsies uitgewys en drie instrumente is ontwikkel en getoets ten einde die teorie onder vennote en belanghebbendes te toets. Multiveranderlike tegnieke, naamlik faktortegnieke en groepsanalise is op die data toegepas en die bevindinge het vyf breẻ aanpassingstrukture aangedui, waarvan drie met die ceorie coreengestem hel die vierde oor die grense van twee keuses geposisioneer is en die vyfde wat langs 'n derde dimensie wal dew die teorie aangedui is, geposisioneer is, naamlik die kollektiewe waardes van die topbestuurspan. Dit het voorgekom asof 'n groot aantal professionele organisasies nog steeds suksesvol vanuit die basis van hulle professionele reputasie funksioneer, maar dat daar eweneens ook ' $n$ aantal was wat meer innoverende benaderings toepes.

*Author to whom correspondence should be addressed.

\section{Introduction}

The growing body of knowledge about organizational behaviour (covering such areas as structure, strategy, culture, decision-making and the interface between organizations and their environments) has been limited to industrial organizations about which information is readily available, and has largely neglected professional service organizations. The various strategic typologies which have been proposed for industrial and service organizations (Miles \& Snow, 1978; Porter, 1980; Miller \& Friesen, 1977, etc.) may not cover the characteristics of professional service organizations. The lack of such research is partly due to the difficulties of gaining access to organizations which deal with sensitive and confidential matters.

Yet there is evident need for insights into professional service organizations. In the 1990 s they are having to change their traditional modus operandi under the impact of extemal socio-economic factors, lechnology, and increasing competition from non-professional firms. They consequently show signs of reaching a mature stage of their evolution, such as declining profits, and are therefore increasing their marketing activity, despite traditionally having disdained 'commercialism' as contrary to the professional ethic.

However, no researched models existed of the strategic and organizational adaptation of professional organizations to these circumstances. The enquiry reponted below was $2 x$ cordingly undertaken to develop a generic typotogy of strategy, organizational adaptation, and the perceptions and values of the top management team, that would be applicable to service organizations in different professions and across different industries.

\section{Theoretical review}

\section{Typologies of organizations and strategies}

The initial observation of Andrews (1971) that the strategy of an organization is an arful alignment of environmenc, re. sources and values was differentialed by Hofer's (1975) contingency theory of stralegy, which suggested that business-level strategies could be classified into generic groups either on a broadly applicable basis (Abell, 1980. Miles \& Snow, 1978; Poner, 1980), or for various contingency situations (Hofer, 1980, Harrigan, 1983, 1985; Woo \& Cooper, 1981). Organizations themselves have atso been classified into archetypes or 'gestaths' in Filley \& Atdag's (1978) typology and the sudies by Miller \& Friecen $(1977,1980)$. However, neither of these typifications was done on service organizations or their stralegies.

Professional service organizations differ from industrial organizations in a number of ways. They are characterized by a high degree of self-management and collegial control. 
since only ocher professionals are held to be in a position to evaluate their peers. There is also a great deal of personal autonomy in defining problems and generating their solutions, without pressure from non-members of the profession.

Professional organizations are further characterized by a particular coupling with their client organizations in the service production process, during which the client effectively becomes a temporary employee of the professional firm, since the information he or she provides is the initial 'raw material'. This highly flexible interface has been shown to be critical (Mills \& Margulies, 1980), and therefore has to be considered in constructing a model.

There are two opposing schools of thought on organizations and their relationships with their environment. In the deterministic or contingency school, organizations are seen to be dependent on, and reactive to, changes in the environment (Dill, 1958; Emery \& Trist, 1965; Lawrence \& Lorsch, 1967; Perrow, 1967; Thompson, 1967; and Duncan, 1972). The interpretive school, by contrast, emphasizes managerial choice and the environment is regarded as created by members of the organization (Weick, 1969; Child, 1972; Montanari, 1978). However, the two schools are alike in tending to define the organization as the focal point and to perceive its relationship to the environment in terms of resources and sources of uncertainty (Bourgeois \& Singh, 1983; Dess, 1987).

A third, more interactive view, seeks to combine the natural selection with the strategic choice perspectives, by emphasizing the adaptation process in organizations. It proposes a typology of organizations, and also the strategic options which would be found in each type as a dynamic equilibrium is attained between organizations and their environments (Hrebiniak \& Joyce, 1985). This is illustrated in Figure 1.

The first quadrant of this model represents high environmental determination with low strategic choice, and illustrates organizations working under perfectly competitive markets with limited options. This would include small organizations selling commodity-type products and large organizations with undifferentiated services, with no way of achieving lasting competitive advantage. The strategies

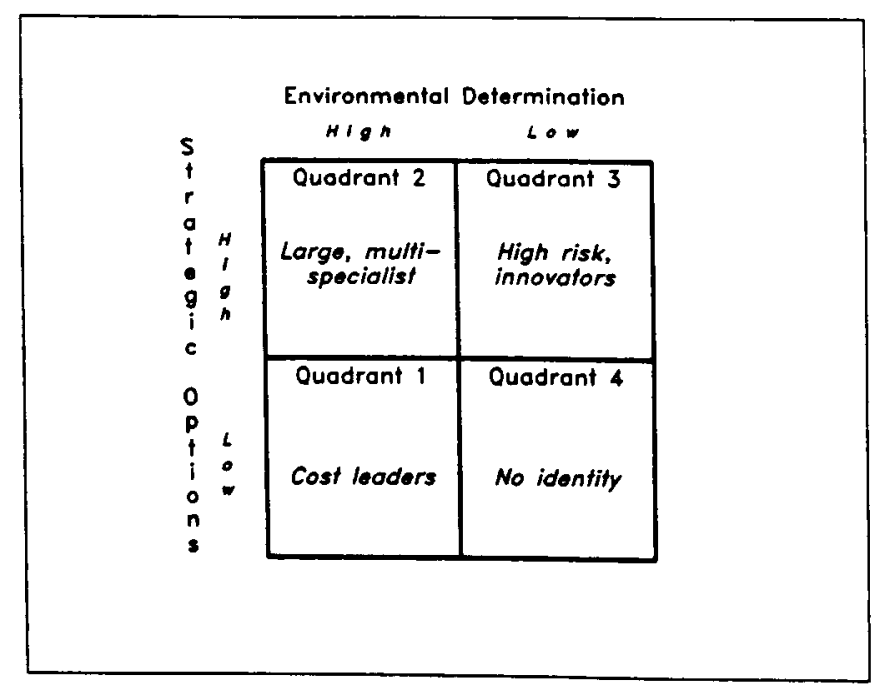

Flaure 1 Hrebiniak \& Joyce (1985) typology of organizations found in this quadrant correspond to those of the costleadership type in Porter's (1980) typology, or the defender type in Miles \& Snow's (1978) typology.

The second quadrant represents high environmental determination with high strategic choice, where differentiation has been made within environmental constraints. This is the situation of large organizations in highly regulated industries. Focused niches may be achieved within the constraints through advertising, lobbying and marketing. The high regulation suggests that professional organizations may well be found in this quadrant. It corresponds to the differentiation and focused strategies of the Porter (1980) typology or the analyzer strategy of the Miles \& Snow (1978) typology.

The third quadrant represents low environmental determination and high strategic choice, with adaptation by design. Differentiated or focused choice may be made, since innovations and proactive behaviour are easier. These organizations correspond again to the differentiation and focused strategies of the Porter (1980) typology, but are the prospector types of the Miles \& Snow (1978) typology. One may expect some professional organizations to fall into this type by having been proactive enough to sustain a niche position.

The fourth quadrant represents low environmental determination and low strategic choice. These organizations work under placid conditions, and their strategies appear to correspond to the unstable reactor type in the Porter (1980) typology, with no clear membership of any strategic group. Some professional organizations may presumably also fall into this group.

\section{Top management team}

There is also an interplay between the environment and the top management teams of organizations through the latter's perception of and interactions with clients, co-operative organizations and competitor organizations. Hambrick \& Mason (1984), drawing on Child's (1972) strategic choice paradigm, have proposed in their 'upper echelons' model that under conditions of bounded rationality selected perceptions and values will influence the strategic choice decision, such as innovation, diversification, acquisition and strategic alliances. In addition, perception of uncertainty in the environment by managers of the organizations will influence their strategic decision-making, and therefore need to be included in the research model. Finally, corporate culture, in the broad sense a shared organizational value system, must be a key element in the management team component of a theoretical model. In other words, it is proposed that the perceptions and values of the top management team add additional contingencies to a proposed integrated model of strategy and professional organization.

Integrated model of strategy, professional organization and the perceptions and values of the top management team

On the strength of the literature, while being mindful of the characteristics of professional service organizations, we have arrived at an integrated model, depicted in Figure 2. It 
proposes a dynamic interactive system, whereby the strategic choices of the top management team interact with the organizations' strategy, structure and culture, as well as with aspects of the environment, to produce various configurations of organizational effectiveness. The shaded area surrounding the various interacting units represents the integration of strategy, organization and the profiles of the top management team as a whole, at times also including those components of the environment who are closely involved in the service production process, such as clients, competitors and other strategic stakeholders (see Figure 2).

\section{Methodology}

In order to assess the model in Figure 2, a primarily inductive approach to the research was adopted, allowing empirical findings to intimate the implications rather than hypothesizing them in detail in advance.

\section{Population definition and sampling procedure}

The choice of professions included in the research was based on the classification by Bennion (1969), who classified the consulting professions under three broad headings, those of health, rights and property. The professions chosen for the research were from each of these three categories: the physician in the health category, the attorney in the rights category, the accountant from the money category of property, and architecture, quantity surveying and consulting engineering in the land and buildings category of property.

The choice of firms was limited to the larger firms within these six professions, since these were presumed to be more likely to be run in an explicably formulated business-like manner. In the medical profession this resulted in only the specialized areas of pathology and radiology being included in the research, since these specializations were the only ones where firms of any size were found. Consulting engineering firms were restricted to multi-disciplinary firms, which eliminated firms which specialized in purely civil, electrical or mechanical engineering.

The population in each profession was determined

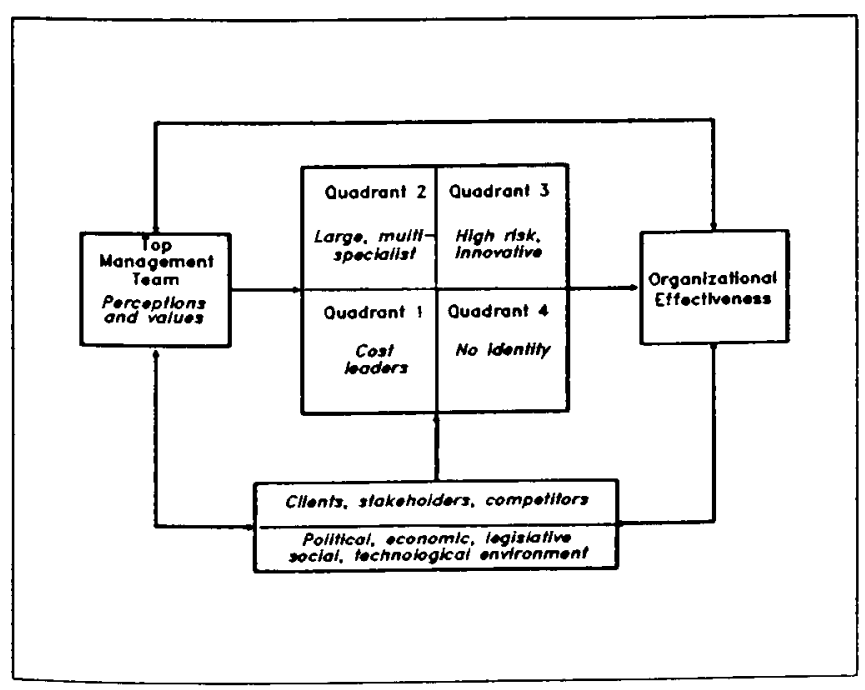

Figure 2 Integrated model of professional service organizations through the use of a quasi-Delphi technique (Dalkey \& Helmer, 1963), whereby the opinions of 'experts', or knowledgeable individuals in the industries in which the profession operated, were used. The aid of knowledgeable individuals at the professional associations was solicited to assist in the initial identification of the major firms.

The process of obtaining expert opinion was repeated with a number of other knowledgeable individuals, including the members of the selected firms, until a final list of 96 firms in the six professions was oblained for the research population.

\section{Sample design}

A probability-proportional-to-size random sample of professional firms from each profession was taken, to ensure that constructs were generated and used which would be representative, and to enhance generalizability. Then written permission was obtained from the participating firms to approach their clients for the purpose of establishing stakeholder image of the firms. From these lists a database of clients was built up for each profession, which was representative of the possible client base which the participating firms could have. The sample frame for each profession was tested for adequacy of representation against an external source, for example, for accounting firms, the sectors of the Johannesburg Stock Exchange, and state and para-statal organizations were used.

\section{Development and testing of research instruments}

Three research instruments were developed and used to measure the different aspects of the above model. The first two, combined into a single questionnaire, were directed to partners of the professional organizations, to measure the perceptions of environmental uncertainty (PEU) which influence their decision-making in the professional organizations, and the personal values which were regarded as important to the partners.

The third instrument, covering image, was designed to measure the perceptions of strategy and professional organization, both by the partners themselves, and by their clients and other stakeholders in the environment who become 'temporary employees' of the professional organization during the service production process.

In order to develop the PEU and value questions, constructs were elicited during in-depth interviews with 27 partners of a sample of 25 professional organizations. The constructs to be used in the image questionnaires were elicited from the same sample, but using the Kelly repertory grid technique.

A list of 34 environmental items and 50 value items were made from the constructs, and 67 respondents from the sample of 25 organizations were requested to indicate agreement or disagreement with the items on a five-point scale. Altogther $90 \%$ of the respondents complied in this phase. The questionnaires were anonymous and distinguished by the type of profession only. To simplify the many statements into more economical scales, the matrices of respondent replies were then subjected to the principal component method of factor analysis. 
In the case of the perceptions of environmental uncertainty, a solution of 13 factors with eigenvalues greater than one resulted, 12 of which were used to construct a semantic differential scale which was subsequently administered.

In the case of the items on values, the initial analysis of the 50 items dealing with values produced a sixteen-factor solution with eigenvalues greater than one. A scree plot of eigenvalues against the number of components confirmed this number, and also indicated a possible nine-factor solution.

However, examination of the loading of the value variables contained in both the solutions did not suggest usable underlying meaning to the factors, in spite of further oblique rotations of the factor scores. This was perhaps because the respondents at this test-stage were not much more numerous than the constructs; or because of substantive variations in value-patterns between sectors or organizations. For this reason, reduction in the number of value variables by factor analysis was postponed to a later stage when a greater sample size might reveal factors with more meaning common to all professions. However, so as not to exhaust the patience of the respondents, the thirty value items with the highest loadings were chosen, and each presented as a sixpoint Likert scale, including a zero to allow for uncertainty of response. These two scales then constituted the first questionnaire.

A similar conservative procedure was applied to items for the third of the three scales regarding the image of the firms as perceived by partners, clients and other stakeholders of the professional organizations. Of the 62 constructs generated through the Kelly repertory grid technique, the 38 constructs with the highest count were retained. They appeared to be categorized into four areas, namely general image of the firms, leadership, marketing, and characteristics of the partners. A semantic differential scale was most appropriate for the form of the items in this questionnaire. A list of participating firms was included with the instructions, and respondents were requested to give their perceptions of their ideal firm, as well as their perceptions of their own firm and competitor furms (in the case of the professional firms) and of their consultant firm (in the case of clients). In this way a perception of each firm by itself, by its competitors, and by its clients, as well as the ideal for each profession would be generated.

\section{Data analysis}

Once the design and testing had been completed, the questionnaires were sent to the partners and clients of 56 professional organizations. Responses were received form 432 partners and 225 clients and stakeholders. A few firms which had taken part in the questionnaire's development phase withdrew from the rest of the research process, so that 48 of the 96 firms were finally included in the analysis.

The internal consistency of the items in the three scales was lested with correspondence analysis (Greenacre, 1984). This indicated that the PEU scale and image scale items were internally consistent, but that there were six variables in the value set which were outliers and which could be removed. In addition, in the case of the image questionnaire,
Kruskal-Wallis' test of the scores representing self-image and client-image showed that there were significant differences $(p<0.01)$ on only two of the 38 variables, so that these two data sets could be merged.

\section{Emplrical results}

With the larger samples in hand, factor analysis with rotation was applied to each of the three sets of items to identify the underlying structures. In deciding how many factors to retain, Youngman (1979) has specified that loadings by at least three variables, with a correlation coefficient of approximately 0.5 or more for orthogonal rotations, are necessary for a factor to be included. Loadings between approximately 0.3 and 0.5 were also considered where these assisted in the interpretation of the factor.

\section{Partner questionnaire}

\section{Perceptions of environmental uncertainty}

The principal component method of factor analysis with a varimax orthogonal rotation produced a three-factor solution using 11 items of the 12-item PEU scale, and accounting for $59 \%$ of the variance. A possible fourth factor was rejected due to the low number of variables loading onto this factor, and one may therefore take the original scaling as validated. In Table 1 the loadings that resulted are shown, and inspection of the contributing variables suggested the corresponding factor descriptions.

\section{Values}

The same factor analysis procedure was performed on the 26 value variables which remained after removal of the outliers. An eight-factor solution accounted for $76 \%$ of the total variance. However, a scree test indicated that only two

Table 1 Factor loadings for three factors of perceptions of environmental uncertainty

\begin{tabular}{llr}
\hline Factor 1 & Known factors, including known oompetition & \\
\hline Variable no. & Description & Loading \\
P4 & Technology & 0.82 \\
P5 & Competition from professional firms & 0.85 \\
P7 & Nature of competition & 0.70 \\
\hline Factor 2 & Unknown competition & \\
\hline Variable no. & Description & Lading \\
P6 & Competition from non-professional firms & 0.67 \\
P8 & Supply of staff & 0.75 \\
P9 & Quality of staff & 0.80 \\
P11 & Demand for new services & 0.35 \\
\hline Factor 3 & Politic-economic risk & \\
\hline Variable no. & Description & Lading \\
P1 & Socio-political factors & 0.81 \\
P2 & Government regulations & 0.71 \\
P3 & Economic factors & 0.76 \\
P12 & Risk & 0.63 \\
\hline
\end{tabular}


major factors appeared to be responsible for $43 \%$ of the variance. A compromise was achieved using Youngman's (1979) criterion, delivering interpretable meaning without trivial detail; and the final number of factors selected was five (see Table 2).

These five factors proved to be confirmed by a factor analysis on the scores for 24 of the original 32 variables which contributed to these factors for each professional organization.

\section{Image}

A similar factor analysis on the merged image data, interpreted with Youngman's criterion, would have yielded seven factors. However, 36 of the 38 variables in the scale had loadings of more than 0.5 and would therefore have

Table 2 Factor loadings for five factors of values

\begin{tabular}{|c|c|c|}
\hline Factor 1 & Service orientation & \\
\hline Variable no. & Description & Losding \\
\hline V5 & competent & 0.55 \\
\hline V6 & compassionate & 0.36 \\
\hline V8 & co-operative & 0.81 \\
\hline V14 & imaginative & 0.79 \\
\hline V22 & nice people & 0.80 \\
\hline V24 & self-disciplined & 0.61 \\
\hline V29 & supponive & 0.73 \\
\hline V30 & tolerant & 0.62 \\
\hline V32 & unselfish & 0.79 \\
\hline Factor 2 & Strength and stability & \\
\hline Variable no. & Description & Loading \\
\hline V1 & adventurous & -0.50 \\
\hline V16 & brond interests & -0.55 \\
\hline V23 & positive/optimistic & -0.52 \\
\hline V27 & stable home life & -0.74 \\
\hline V28 & strong personality & -0.65 \\
\hline Factor 3 & Credibility & \\
\hline Variable no. & Description & Loading \\
\hline $\mathbf{V} 2$ & ambitious & 0.33 \\
\hline V3 & academic & 0.90 \\
\hline V10 & experienced & 0.45 \\
\hline Factor 4 & Leadership & \\
\hline Variable no. & Description & Loading \\
\hline V4 & broad vision & -0.77 \\
\hline V18 & leadership qualities & -0.78 \\
\hline V23 & positive & -0.34 \\
\hline Factor 5 & Interpersonal skills & \\
\hline Variable no. & Description & Loading \\
\hline v9 & courteous & 0.77 \\
\hline$V_{12}$ & good judgement & 0.51 \\
\hline V15 & interpersonal skills & 0.52 \\
\hline $\mathbf{v 2 0}$ & methodical & 0.64 \\
\hline
\end{tabular}

been included in this seven-factor solution, defeating the aim of reducing the number of variables. A more stringent requirement was therefore set for factor loadings higher than 0.6 , which left 22 scale items. This sifting procedure was equivalent to scale construction.

A factor analysis of these 22 scale items, again using the Youngman criterion, suggested that there were four factors which summarized the underlying 22 variables meaningfully. These are described in Table 3, with the factor labels suggested by the contributing variables.

An integrated configuration comprising professional organization, strategy, and the perceptions and values of the top management team

The factor scores for each respondent from the three analyzes comprised the reduced data set. Based on the approach suggested by Harrigan (1985), a cluster analysis of the twelve-factor scores was performed, with various possible cluster solutions being examined, from four clusters to seven. It was tempting to choose a four-part taxonomy as

Table 3 Factor loadings of four image factors

\begin{tabular}{|c|c|c|}
\hline Factor 1 & Quality service & \\
\hline Variable no. & Description & Loading \\
\hline 116 & good leadership & 0.69 \\
\hline 121 & good connections with clients & 0.74 \\
\hline 129 & good service & 0.80 \\
\hline 132 & depth of experise & 0.83 \\
\hline 133 & technical knowledge & 0.86 \\
\hline Factor 2 & Broad, multi-specialist & \\
\hline Variable no. & Description & Loading \\
\hline 117 & autocratic leadership & 0.52 \\
\hline 130 & many specialist services & 0.80 \\
\hline 134 & high morale & 0.85 \\
\hline 15 & ethical & 0.62 \\
\hline 125 & wide range of services & 0.76 \\
\hline 19 & specific language/cultural idemity & 0.50 \\
\hline 16 & stable & 0.89 \\
\hline 112 & unifom identity & 0.73 \\
\hline Factor 3 & Reputable professionals & \\
\hline Variable no. & Description & Londing \\
\hline 17 & growing & 0.64 \\
\hline 14 & good reputution & 0.75 \\
\hline 124 & aggressive marketers & 0.34 \\
\hline 123 & involved in the professions & 0.80 \\
\hline I38 & well-known stars & 0.72 \\
\hline Factor 4 & Innovative specialists & \\
\hline Variable no. & Description & Loeding \\
\hline 13 & imnovative & 0.81 \\
\hline 114 & progressive & 0.45 \\
\hline 128 & strong in certain markets & 0.50 \\
\hline 115 & specialias & 0.46 \\
\hline
\end{tabular}


Table 4 PEU, value, and image factor scores, and means, for the five-cluster solution

\begin{tabular}{lccccc}
\hline Factor & Group 1 & Group 2 & Group 3 & Group 4 & Group 5 \\
\hline Perceptions of environmental uncertalnty & & & & \\
\hline Known factors & -1.07 & 0.21 & -0.02 & 1.33 & 0.17 \\
Competition & -0.65 & 0.26 & 0.06 & 0.66 & -0.55 \\
Politico-econ. factors & -0.82 & 0.37 & -0.32 & 0.21 & -1.70 \\
Mean & -0.30 & 0.28 & -0.09 & 0.73 & -0.69 \\
Values & & & & & \\
Service orientation & -0.14 & 0.00 & 0.07 & 1.18 & -1.22 \\
Interpersonal skills & 0.61 & -0.93 & 0.50 & -0.15 & -0.04 \\
Leadership & -1.06 & 0.07 & 0.17 & 0.60 & 0.50 \\
Credibility & -0.56 & 0.38 & 0.17 & -0.45 & -0.54 \\
Strength & 0.45 & 0.20 & 0.16 & -0.10 & -2.24 \\
Mean & -0.14 & -0.06 & 0.21 & 0.22 & -0.71 \\
Images & & & & & \\
Service quality & -0.14 & 0.42 & 0.23 & -2.28 & -0.05 \\
Multi-speciality & 0.04 & 0.41 & -0.04 & -0.90 & -0.39 \\
Reputable & -0.27 & -0.64 & 0.76 & 0.18 & -0.80 \\
Innovative & -0.19 & 0.41 & -0.28 & 0.30 & -0.05 \\
Mean & -0.14 & 0.15 & 0.17 & -0.68 & -0.32 \\
\hline
\end{tabular}

suggested by the theory. However, inspection of the stepwise grouping of the firms, for the decreasing number of clusters provided by the statistical technique, indicated a counter-intuitive rearrangement of firms if one dropped below five clusters. A five-cluster solution was therefore adopted as reasonably close to what the theory had to offer, yet providing the most satisfactory fit with the data.

This five-cluster solution, based on the three PEU, five value and four image factors, was taken as the foundation of the integrated typology. The twelve factor scores under each type are illustrated in Table 4.

A three-dimensional plot of the means of these factor scores is presented in Figure 3 in order to facilitate the discussion below. This plot, read in conjunction with the factor scores for each type, suggested summary labels for each of the five types; sentient, capable, reputable, uneven and amorphous, respectively.

Shown in Figure 4 are the five groups superposed on the four-cell theoretical model of Figure 1.

\section{Discussion}

By interpreting the relative mean factor scores of the types, the following overall descriptions were achieved of each group and its membership.

\section{Group 1: Sentient}

This group consists of three organizations from the medical profession, three from the legal profession and one each from the architectural and accounting professions. One sees that their perception of the environment as uncertain are limited to politico-economic factors; uncertainty is low on known factors and on competition. They are comforable with their competitive environment.

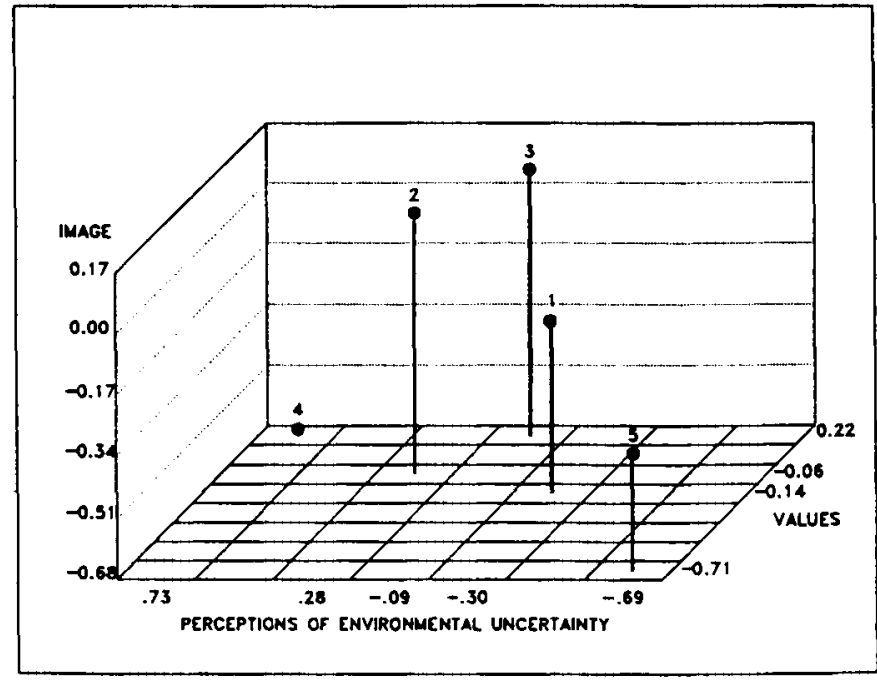

Figure 3 Means of PEU, value and image factor scores for the five-cluster solution

Their values reflect the importance of interpersonal skills and strength. That these organizations do not exhibit any particularly strongly defined image can be interpreted to mean that they have low strategic choice. They are not differentiated, and can therefore be positioned in the fourth quadrant of the theoretical model.

Hrebiniak \& Joyce (1985) have described this position as a relatively placid situation where organizations have no coherent strategy, likening their strategies to 'muddling through'. They further suggest that these organizations could have an array of internal competencies and strengths which are inappropriate to external opportunities and conditions. They represent the reactors of the Miles \& Snow (1978) typology. 


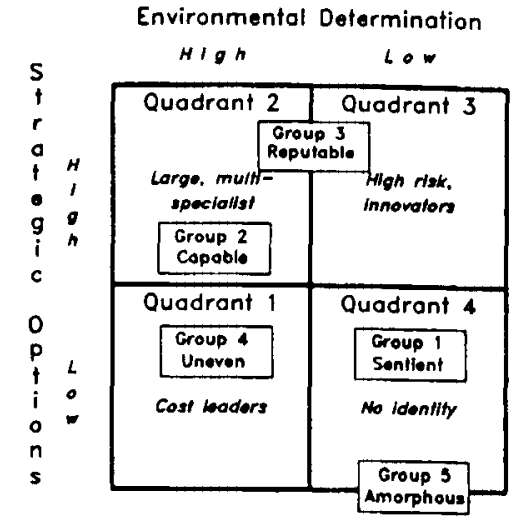

Figure 4 Five-group classification of professional service organizations compared to the Hrebiniak \& Joyce (1985) typology

\section{Group 2: Capable}

Organizations in this group are uniformly capable, multispecialist, diversified and innovative. They have a fairly high perception of uncertainty of all environmental factors. They espouse the value of credibility, and are fairly high on all image factors, particularly service quality, multi-specialization and innovation, relative to those in other groups.

The group includes five architectural, two quantity surveying, two engineering, one accounting, two legal, and two medical organizations. Since these organizations exhibit a high perception of uncertainty of all the environmental factors, it appears that there is a high degree of environmental determination. However, the clearly defined and mixed strategic choices manifested in the strong image profile indicate high strategic choice by the top management team. Organizations in this group value credibility, but they do not regard interpersonal skills as important as do the other groups.

According to Hrebiniak \& Joyce (1985), organizations in this quadrant, in contrast to those in the fourth quadrant, operate in turbulent conditions. Although certain environmental constraints, such as high regulation in terms of legal constraints or ways of conducting business, may severely affect organizational adaptation under these conditions, strategic choice remains high due to the ability of these organizations to choose single or multiple market niches, often through extensive advertising, lobbying and marketing activity.

Nine out of the fourteen organizations in this group are from the building and construction industry, more than the proportion from this industry in the overall sample. It may be that features of this industry are operating as a determinant, and other organizations in the group exhibit some of the characteristics of this industry.

\section{Group 3: Reputable}

Group 3 consists of seven accounting, five legal and five engineering organizations. Since their perceptions of environmental uncertainty are fairly neutral or negative, they experience slightly low environmental determination. They exhibit a strong image of being reputable, but do not have other strongly defined image attributes. Their overall image is the highest of all the groups, which is interpreted as meaning that they exhibit the highest strategic choice. Most of the professional organizations in the sample, 18 of 48 , fell into this group, indicating that reliance on their professional reputation remains the dominant choice of these organizations.

\section{Group 4: Uneven}

The organizations in Group 4 have the highest perception of environmental uncertainty, and are characterized by having an image of innovation which is supponted by the highest amount of diversified services. But they are the least broadly based, which in all reflects a focused strategy in Porter's (1980) sense.

The values of this group of organizations reflect a strong service orientation and leadership. Because of their high environmental determination, overall low strategic choice and image of innovation, this group could be placed in the first quadrant - those representing the defenders of the Miles \& Snow (1978) typology. The group consists of three organizations from the architectural profession, which is not surprising in terms of the image of innovation, and one from the medical profession.

The characteristics of this quadrant include small organizations in imperfectly competitive niches, with limited managerial choice, although individuals may attempt to exercise options which mitigate against environmental demands, and technological innovations may alter their ability to compete and affect their competitive advantage (Hrebiniak \& Joyce, 1985). The image of innovation exhibited by this group of organizations may reflect their attempt at changing their domain, or it may be the consequence of the fact that three of the four organizations are from the architectural profession, with highly innovative values.

\section{Group 5: Amorphous}

The four organizations in Group 5 have the lowest perception of environmental uncertainty and no clearly defined strategic choice which may be identified in its image, except that they are perceived to be less reputable and less broadly based than those in other groups. The value of leadership is regarded as important. These organizations can thus be categorized as belonging to the fourth quadrant of the theoretical model which represents low strategic choice and low environmental determination as articulated in the perceptions of environmental uncentainty by the members of the top management team. There is a similarity between the organizations in this group and organizations in the first group, except for the differences in their perceptions of the uncertainty of the politico-economic factor and their value profile. Two of the firms in this group were from the medical profession and two from the engineering profession.

\section{Conclusion}

In summary, the empirical enquiry found five broad configurations, three of which could be associated with three of the four quadrants of the theoretical typology of Hrebiniak \& Joyce (1985), defined by environmental determination 
and strategic choice. A fourth configuration overlapped two of the quadrants; and a fifth moved above a particular quadrant into a third dimension, that of the collective values of the top management team of the professional organizations.

It appears that for a large number of professional organizations, one of the strategic bases from which to operate is their professional reputation, particularly in the commercial industry, and in the uncertain South African environment where clients look to their professional consultants to help reduce their risk and uncertainty.

Contained among the more innovative organizations in the capable group (with high strategic choice), and the uneven group (with low strategic choice), were eight of the nine organizations from the architectural profession. This finding is interesting in view of the 'avant-garde' nature of this profession.

It is also noteworthy that most of the organizations in the medical profession operate from a position of low strategic choice. This is probably a reflection of the influence of commercial considerations over radiology and pathology specializations, which frequenty function within private hospital groups, and under a more established fee structure.

No group was positioned in the third quadrant of the theoretical model, where maximum choice and low environmental determination occur, resources are lacking, entry and exit barriers are low, and organizations may define and enact their own environments. However, it was pointed out that organizations in Group 3 exhibited some attributes of this quadrant. It is likely that some of the organizations contained within this cluster have poised themselves to take advantage of this position, but are still too constrained by such environmental determinants as regulation, lack of resources, and lack of autonomy and control over others in the environment, to fully exploit the advantages which this position offers. It may also be that commercial competitors (the professional organizations in this sample), to have an advantage in this respect, would be found to occupy this quadrant.

This research has shown that many of the theoretical propositions regarding strategy, organizational adaptation and the effect of the top management team, which had been suggested for industrial organizations, are likely to be true for professional organizations. In particular, the typologies of Porter (1980), Miles \& Snow (1978), Hrebiniak \& Joyce (1985), and the models of Child (1972) and Hambrick \& Mason (1984) discussed at the outset, have proved to be enlightening in attempting to arrive at archetypes of professional service organizations, provided that they are suitably refined on the basis of empirical evidence of the profile of top management teams in the face of South African environmental circumstances.

\section{References}

Abell, D.F. 1980. Defining the business: The starting point of strategic planning. Englewood Cliffs: Prentice Hall.

Andrews, K. 1971. The concept of corporale strategy. New York: Dow Jones, Irwin.

Bennion, F.A.R. 1969. Professional ethics. London: Charles Knight.
Bourgeois, L.B. \& Singh, J. 1983. 'Organizational slack and political behaviour within top management teams', Academy of Management Proceedings, pp.43-47.

Child, J. 1972. 'Organizational structure, environment and performance: The role of strategic choice', Sociology, Vol. 6: 1-22.

Dalkey, N. \& Helmer, O. 1963. 'An experimental spplication of the Delphi method to the use of experts', Management Science, Vol. 9: 58-67.

Dess, G.G. 1987. 'Consensus on strategy formulation and organisational performance: Competitors in a fragmented industry', Strategic Management Journal, Vol. 8: 259-277.

Dill, W. 1958. 'Environment, structure and consensus in strategy formulation', Academy of Management Review, Vol. 12. April.

Duncan, R.G. 1972. 'Characteristics of organizational environments and perceived environmental uncertainty', Administrative Science Quarterly, Vol. 17, No. 2: 313-327.

Emery, F.E. \& Trist, E.L. 1965. 'The causal texture of organizational environments', Human Relations, February: 21-32.

Filley, A.C. \& Aldag, R.J. 1978. 'Characteristics and measurement of an organizational typology'. Academy of Management Journal, Vol. 21, No. 4: 578-591.

Greenacre, M.J. 1984. Theory and application of correspondence analysis. London: Academic Press Inc.

Hambrick, D.C. \& Mason, P.A. 1984. 'Upper echelons: The organization as a reflection of its top managers', Academy of Management Review, Vol. 9, No. 2: 193-206.

Harrigan, K.R. 1983. 'Research methodologies for contingency approaches to business strategy', Academy of Management Review, Vol. 8, No. 3: 398-405.

Harrigan, K.R. 1985. 'An application of clustering for strategic group analysis', Strategic Management Journal, Vol. 6: 55-73.

Hofer, C.W. 1975. 'Towards a contingency theory of business strategy', Academy of Management Journal, Vol. 8: 784-810.

Hofer, C.W. 1980. 'Tumaround strategies', Journal of Business Strategy, Vol. 1: 19-30.

Hrebiniak, L.G. \& Joyce, W.F. 1985. 'Organizational adaptation: Strategic choice and environmental determinism', Administrative Science Quarterly, Vol. 30: 336-349.

Lawrence, P.R. \& Lorsch, J.W. 1967. Organization and environment. Boston: Harvard University Press.

Miles, R. \& Snow, C.P. 1978. Organizational strategy, structure and process. New York: McGraw Hill.

Miller, D. \& Friesen, P.H. 1977. 'Strategy-making in context: Ten empirical archetypes', Journal of Management Studies, Vol. 14: 253-280.

Miller, D. \& Friesen, P.H. 1980. 'Archetypes of organizational transition', Administrative Science Quarterly, Vol. 2: 268-299.

Mills, P.K. \& Margulies, N. 1980. 'Towards a core typology of service organizations', Academy of Management Review, Vol. 5, No. 2: 255-265.

Montanari, J.R. 1978. 'Managerial discretion: An expanded model of or ganizational choice', Academy of Management Review, April, pp.23i-241.

Perrow, C. 1967. 'A framework for the comparative analysis of organizations', American Sociological Review, Vol. 32: 196-208.

Porter, M.E. 1980. Competitive strategy. New York: Free Press, Macmillan. 
Thompson, J.D. 1967. Organizations in action. New York: McGraw-Hill.

Weick, C. 1969. The social psychology of organizing. Reading: Addison Wesley.

Wo, C.Y.Y. \& Cooper, A.C. 1981. 'Strategies for effective low- share businesses', Strategic Management Jowrnal, Vol. 2: 301-318.

Youngman, M.B. 1979. Analysing social and educational to research data. London: MoGraw-Hill. 